\title{
Türkiye'de Hemşirelik Alanında Üriner İnkontinansla İlgili Yapılan Lisansüstü Tezlerin İncelenmesi
}



'Adıyaman Üniversitesi, Sağlık Yüksekokulu, Ebelik Bölümü, Adıyaman, Türkiye 2Dokuz Eylül Üniversitesi, Hemşirelik Fakültesi, Kadın Sağlığı ve Hastalıkları Hemşireliği Anabilim Dalı, İzmir, Türkiye

3̇stanbul Biruni Üniversitesi, Sağlık Bilimleri Fakültesi, Hemşirelik Bölümü, İstanbul, Türkiye

Semiha Aydın Özkan, Dr. Öğr. Üyesi Dilek Bilgiç, Dr. Öğr. Üyesi Nezihe Kızılkaya Beji, Prof. Dr.

Iletişim:

Dr. Öğr. Üyesi Semiha Aydın Özkan Adıyaman Üniversitesi Sağık Yüksekokulu, Ebelik Bölümü, Adıyaman, Türkiye Tel: +905348894218

E-Posta: semihaaydin44@gmail.com

Gönderilme Tarihi : 05 Haziran 2017

Revizyon Tarihi : 11 Eylül 2017

Kabul Tarihi : 17 Eylül 2017

\section{ÖZET}

Amaç: Bu çalışmada Türkiye'de hemşirelik alanında üriner inkontinans konusunda yapılan yüksek lisans ve doktora tezlerinin taranması amaçlanmıştır.

Yöntem: Çalışmanın evrenini Yükseköğretim Kurulu Ulusal Tez Merkezi'ne kayıtlı 2000-2016 yılları arasında Hemşirelik ve Doğum ve Kadın Hastalıkları Hemşireliği Anabilim Dalları'nda yapılan doktora ve yüksek lisans tezleri oluşturdu. Bu çalışmada "üriner inkontinans" anahtar kelimesi kullanıldı. Retrospektif tanımlayıı literatür araştırmasında 9 doktora ve 23 yüksek lisans tezi incelendi. Verilerin analizinde tezlerin yüksek lisans ya da doktora tezi oluşu, tezlerin yayın yılı, amacı, örneklem grubu, örneklem sayısı, dizaynı ve sonuçları özetlendi.

Bulgular: Taranan 23 yüksek lisans tezinden 19'i tanımlayııı, $4^{\prime}$ i deneysel; 9 doktora tezinden 1'i kesitsel, $4^{\prime}$ 'ü tanımlayıcı, deneysel ya da prospektif ve 4 'ü de deneysel olarak yapıımıştı. Tanımlayıcı çalışmalarda kadınlarda Üï prevalansı, etkileyen faktörler incelenmiş ayrıca Ül yaşam kalitesine, sosyal yaşama, cinsel sağlığa, dini yaşama etkilerine bakıımış ve depresyonla ilişkileri değerlendirilmiştir. Üi sorunu kadınların yaşam kalitelerini olumsuz etkilediği, dini sorumluluklarını yerine getirmede sorun yaşadıkları ve depresyon ile Üi arasında pozitif bir ilişki olduğu belirtilmiştir.

Sonuç: Üriner inkontinans her yaş grubu kadında yaygın bir şekilde görüldüğü yapılan çalışmalarla tanımlanmış olup yaşam kalitesini olumsuz etkilediği saptanmıştır. Deneysel çalışmalarla pelvik taban kas egzersizleri ile kas gücünün arttırıılığı ve yaşam kalitesini olumlu etkilediği belirtilmiştir. Kadınların yarııına yakınını etkileyen üriner inkontinansın korunması ve tedavisine yönelik hemşireler tarafından daha çok deneysel araştırmaların yapııması önerilmektedir.

Anahtar sözcükler: Üriner inkontinans, hemşirelik, tezler

\section{THE EXAMINATION OF NURSING POSTGRADUATE THESES RELATED TO URINARY INCONTINENCE IN TURKEY}

\section{ABSTRACT}

Purpose: This study aims at reviewing the master's theses and doctoral dissertations on urinary incontinence in the field of nursing in Turkey.

Method: The study sample consisted of master's theses and doctoral dissertations registered in the National Thesis Center of the Council of Higher Education and finished between 2000 and 2016 in Obstetrics and Gynecology Nursing departments. "Urinary Incontinence" was used as a keyword in the study. Carried out with the retrospective descriptive literature research, the study consisted of 9 doctoral dissertations and 23 master's theses. In the analysis of these data, it was summarized that data were classified into master's theses or doctoral dissertations ; also, publication year, purpose, sample group, design then the results were summarized.

Results: Twenty three master's theses are reviewed; it is stated that 19 of them are descriptive, 4 of them are experimental. Nine doctoral dissertations are reviewed; it is stated that one of them is cross -sectional, 4 of them are descriptive, experimental or prospective and 4 of them are experimental. In the descriptive studies, the factors of women's urinary incontinence prevalence are examined. In addition, urinary incontinence's effects on life quality, social life, sexual health, religious life are examined and their relations with the depression are also estimated. It is stated that the urinary incontinence problem affects women's life quality negatively, that they have some problems while performing religious practices .

Conclusion: It is determined in these studies that urinary incontinence can be widely found in each and every age group of women and also it affects negatively women's life quality. In the experimental studies, it is stated that pelvic floor muscle exercises increase pelvic floor muscle strength and it affect positively the women's quality of life. It is suggested that nurses should conduct more experimental research related to the protection and cure of urinary incontinence which affects almost half of the women.

Keywords: Urinary Incontinence, nursing, theses, dissertations 
D ünya Sağlık Örgütü tarafından öncelikli halk sağlığı sorunlarından biri olarak görülen üriner inkontinansı (Üi) Uluslararası Kontinans Topluluğu (International ContinenceSociety-ICS) tarafından 2002 yılında, miktarı ne olursa olsun hertürlü istemsiz idrar kaçırma durumu olarak tanımlanmıştır $(1,2)$.

ICS, Üi tiplerini semptomlarına göre stres, urge, miks tip Üi olarak sınıflandırılmıştır. Stres tipi idrar kaçırma "öksürme, hapşırma, efor ya da fiziksel egzersiz esnasında yaşanan istemsiz idrar kaybı yakınması" semptomları ile tanımlanmış olup; temel neden mesane ve/veya üretrayı destekleyen pelvik taban desteğinin bozulmasıdır. Sıkışma tipi idrar kaçırma ise "sıkışma hissi (urgency) ile birlikte ya da sıkışma hissinden hemen sonra oluşan istemsiz idrar kaybı yakınması" olarak tanımlanmıştır. Miks tip idrar kaçırma ise stres ve sıkışma tipi idrar kaçırma yakınmasının birlikte görüldüğü tablodur (2).

Dünya çapında giderek yaygın bir sorun olarak görülen Üi kadınlarda erkeklere göre daha sık görülen, tüm yaş gruplarını etkileyen, bireylerin iş hayatı, sosyal yaşantı, ikili ilişkileri, cinsel yaşantı gibi her türlü yaşam kalitesini olumsuz etkileyen sağlık sorunudur (3). Dünyada ve ülkemizde cinsiyet ve yaş gruplarında yapılan geniş toplum tabanlı prevalans çalışmalarında kadınlarda ortalama \%18 ile \%45 arasında değiştiği bildirilmektedir ve bu oranların ilerleyen yaşla birlikte arttığı da yapılan çalışmalarda rapor edilmiştir (4-11).

Dünyada ve ülkemizde yapılan çalışmalarda Üi gelişiminde; yaş, cinsiyet, doğum travması, menopoz, beden kitle indeksi (BKI)'nin yüksek olması, ilk doğum yaşı, sigara kullanımı, genetik faktörler, ırk, ürinerenfeksiyon, perineal travma, doğum şekli, histerektomi, geçirilmiş pelvik operasyonlar, östrojen eksikliği, diyabet gibi kronik hastalıklarla gelişen nörolojik hasarlar ve kognitif bozukluklar, alkol, kafein ve tütün kullanımı, düşük fiziksel aktivite, kabızlık, psikososyal bozukluklar ve sosyal tuvalet alışkanlıkları gibi faktörlerin etkili olduğu belirtilmektedir (5,7-11).

Bireylerin yaşam kalitesini olumsuz etkileyebilen ve yaygın bir sağlık sorunu olan Üi sorununun çözümünde, evde bakım uygulamalarında, maliyetin azaltılmasında ve bakım kalitesinin yükselmesinde hemşirelerin etkin rol oynadığı kanıtlanmıştır (12). İnkontinans sorununun önlenmesi ve giderilmesi multidisipliner ekip çalışmasını gerektirmektedir. Hemşireler, bu ekibin en temel ve vazgeçilmez üyelerinden olup, rolleri sürekli genişlemektedir. Holistik bakımı amaçlayan ve sadece klinik bakımdan sorumlu olmayan hemşirelerin, hastanın tanı, tedavi ve izlem/ kontrollerinin yanı sıra kontinansın geliştirilmesi ve inkontinansın önlenmesinde de önemli sorumlulukları vardır $(13,14)$. Kontinans hemşirelerinin hasta bakım kalitesini arttırmak amacıyla yerine getirdikleri temel sorumlulukları mevcuttur. Kontinans hemşirelerinin rol ve sorumlulukları arasında araştırma, klinisyen/uygulayıcı, danışmanlık, sağlığı koruma/geliştirme, eğitim, karar verme, tedavi yönetimi, yönetici, koordinasyon ve iletişim becerileri yer almaktadır (15). Hemşirelik uygulamalarını geliştirecek araştırmaların yapılması ve sonuçlarının uygulama alanına yansıtılması, konferans, kitap ve araştırma makaleler ile de bu mevcut bilginin paylaşıması hemşirelerin sorumluluklarındandır. Hemşireler kendi profesyonel bilgilerini, bakımdaki teorik ve pratik sorunları araştırarak arttırabilmektedirler. Aynı zamanda, hemşireler farklı çalışmaları da değerlendirerek inkontinansın tanı ve tedavi seçeneklerini değerlendirmektedirler $(15,16)$.

Bu retrospektif tanımlayıcı literatür araştırmasında, (i) ülkemizde hemşireler tarafından Üi olan bireylere yönelik yapılan tezleri incelemek, (ii) Üi yönelik yapılan tezlerin sonuçlarını analiz etmek, (iii) araştırmacılara ve Üi olan bireye sağlık hizmeti sunan hemşire ve diğer sağlık personeline somut veriler sunmak amaçlanmıştır.

\section{Yöntem}

Bu retrospektif tanımlayıcı tipte ki literatür araştırmasında 2000 ve 2016 yılları arasında Üi ile ilgili yapılan tezleri belirlemek için Yükseköğretim Kurulu Ulusal Tez Merkezi veri tabanı tarandı. Tarama yapılırken "Üriner İnkontinans" anahtar kelimesi kullanıldı. Ulaşılan tezlerden Hemşirelik ve/veya Doğum ve Kadın Hastalıkları Hemşireliği Anabilim Dalı'nda yapılan doktora ve yüksek lisans tezlerinden 32 tez incelendi. Bu araştırmada incelenen tezlerin araştırmaya alınma ölçütleri; başlığında Üriner İnkontinans kelimelerinin yer alması, Hemşirelik ve/veya Doğum ve Kadın Hastalıkları Hemşireliği/ Kadın Sağlığı ve Hastalıkları Hemşireliği Anabilim Dalı tarafından yapılmış olmasıdır. Araştırmaya alınmama ölçütleri ise; başlığında Üriner Inkontinans kelimesi geçmesine rağmen farklı disiplinler tarafından tezlerin yapılmış olmasıdır. Araştırma için belirlenen anahtar sözcüklerin taranması sonucu elde edilen tezler katma ve dışlama ölçütlerine göre değerlendirildi ve ölçütlere uygun olmayan tezler elendi. Ulaşılan tezler başlıklarına göre değerlendirildi ve 192 tezden ilgili olmayan 161 tez kapsam dışı bırakıldı. Toplam 32 tez araştırmaya alındı. Araştırmaya alınan tezlerin 9'u doktora ve 23'ü yüksek lisans tezidir. Doktora tezlerinden 2 tanesine, yüksek lisans tezlerinin 6 tanesine özet olarak ulaşıldı.

Retrospektif tanımlayıcı tipte bu literatür araştırmasının etik kurul raporu bulunmamaktadır. 
Tezler yüksek lisans ve doktora tezleri olarak ayrıldıktan sonra kronolojik sırayla incelendi. Verilerin analizinde sayısal değerlendirmeler kullanıldı ve tezlerin yüksek lisans ya da doktora tezi oluşu, tezlerin yayın yılı, tezlerin amacı, örneklem grubu, örneklem sayısı, tezlerin dizaynı ve tezlerin sonuçları özetlendi.

\section{Bulgular}

Bu sistematik inceleme çalışmasında, 2000-2016 yılları arasında yayınlanan 33 tezde toplam 8565 katılımcı yer almaktadır. Yüksek lisans tezlerinin yayın yılı amacı çalışma tipi örneklem sayısı ve sonuçları Tablo 1'de, doktora tezleri ise Tablo 2'de özetlendi.

Tablo 1'de görüldüğü gibi yüksek lisans tezlerinden 9 tanesinde farklı bölgelerde farklı yaş gruplarında Üi prevalansına yönelik çalışmalar yapılmıştır. Ankara'da bir Sağlık Ocağı Bölgesine bağlı 15 yaş üstü, evli kadınlarda stres Üi yaygınlığı araştıran çalışmada 240 kadından \%41.7'sinde stres Üi olduğu saptanmıştır (17). Jinekoloji polikliniğine başvuran 20 yaş üstü doğum yapmış 229 kadının \%37'sinde Üi bulguları saptanmıştır (18). Sivas il merkezinde 15 yaş üstü doğum yapmış 800 kadında stres Üi prevalansı \%20.1 olarak saptanmıştır (20). Gülveren sağlık ocağı bölgesinde 20 yaş üstü evli 610 kadının \%22.6'sında Üi olduğu belirlenmiştir (21). Kırklareli il merkezinde 40 yaş üstü 435 kadının \%48.3'ünde Üi olduğu saptanmıştır (22). Dokuz Eylül Üniversite Hastanesi Kadın Hastalıkları ve Doğum Polikliniği ve Servisine ve Üroloji Polikliniğine başvuran ve normal vajinal doğum yapmış 40 yaş ve altı 250 kadınla yapılan çalışmada Üi prevalansı \%34.8 olduğu görülmüştür (25). Akşehir ilçesinde yaşayan 65 yaş ve üzeri 268 kadının \%47.8'inde Üi olduğu ve bu Üi yaşayan kadınlarda en sık miks tip Üi (\%51.6) görüldüğü saptanmıştır (29). İstanbul Bakırköy ilçesinde yapılan çalışmada 15-24 yaş arası 726 kız öğrenci arasında inkontinans tipleri olarak \%8.9 stres, \%5.6 urge ve \%.3.0'nın da miks tip inkontinans görüldüğü saptanmıştır (32). Yıldırım Beyazıt Üniversitesi Atatürk Eğitim ve Araştırma Hastanesi Jinekoloji Polikliniği'ne başvuran 18 yaş ve üzeri 150 kadın arasında Üi prevelansının \%86.7 olduğu ve \%59.2 ile miks tipin en yüksek oranda görüldüğü bildirilmiştir (33). Otuzbeş yaş üstü 300 kadın ile yapılan başka bir çalışmada kadınların \%48'inde Üi varlığı saptanmıştır (36). 18 yaş ve üzeri 1200 kadın ile yapılan bir çalışmada Üi yaşayan kadınların \%26.3 olarak belirtilmiştir (38). Diyabet tanısı alan 383 kadın ile yapılan çalışmada Üi prevalansı $\% 43.6$ olarak belirtilmiştir (39).

Altı yüksek lisans tezinde Üi'ı etkileyen faktörler araştırılmıştır. Kocagöz'ün (2001) çalışmasında yaş, gebelikte idrar kaçırma şikâyeti, geçmişte stres Üi varlığı stres Üi gelişmesi üzerinde direkt etkisinin olduğu belirtilmiştir (17). Acar Bektaş'ın (2007) çalışmasında 15 yaş üstü evli kadınlarda yaş, eğitim seviyesi, gebelik sayısı, parite ve BKI arttıkça stres Üi sıklığının da artı̆̆ı saptanmıştır (20). Karasaç'ın (2011) çalışmasında kadınlarda BKI ve doğum sayısı arttıkça Üi prevalansının arttığı saptanmıştır (25). Demirel'in (2012) çalışmasında 65 yaş üzeri kadınlarda ileri yaş, kötü ekonomik durumu, 1-2 doğumu olanlar, çoğul gebelik, mesane prolapsusu, üç ve üzerinde kronik hastalığı olan ve ilaç kullanan kadınlarda Üi daha fazla görüldüğü saptanmıştır (29). Aksu Sucuoğlu'nun (2014) çalışmasında 1524 yaşarası kız öğrencilerde çocukluğunda tuvalet eğitimi sonrası geceleri idrar kaçırma problemi olan, sürekli idrar yolu enfeksiyonu yaşayan, idrarını tutma/erteleme alışkanlığına sahip olan, sigara içen öğrencilerde Üi yaşama oranının yüksek olduğu saptanmıştır (32). Akkuş'un (2014) çalışmasında 18 yaş üstü kadınlarda yaş, gebelik sayısı, parite, BKI, menopoz, doğum şekli, prolapsus ve sigara kullanımının Üi riskini artırdığı saptanmıştır (33). Baykuş'un (2016) çalışmasında Üi'ın yaş ve Beden Kitle Indeksine (BKi) bağlı olarak arttığı, uzun süreli konstipasyon yaşayan, uzun süreli idrar yolu enfeksiyonu IYYE geçiren, kronik hastalığı olan, ailesinde Üi öyküsü olan, menopoz döneminde olan, gebelik, düşük ve doğum sayısı yüksek olan, vajinal doğum yapan kadınlarda Üi oranı yüksek saptanmıştır (38).

Yüksek lisans tezlerinin 10'undaÜi'ın kadınların sosyal yaşantılarının ve yaşam kalitesinin nasıl etkilediği araştırılmıştır. Kök'ün (2005) çalışmasında Üi kadınları psikolojik yönden en yüksek düzeyde etkilediği saptanmıştır (18). Farklı ölçeklerle bakılan yaşam kalitesi tezlerinde Üi kadınlarda yaşam kalitesini olumsuz yönde etkilediği saptanmıştır $(19,21,22,24,28,29,30,32,33,34)$.

Yapılan 2 yüksek lisans tezinin birinde stres ÜI'lı 36 kadına yaşam kalitesini yükseltmek için pelvik taban kas egzersizleri eğitim verildiği ve verilen eğitimin yaşam kalitelerini arttırdığını saptanmıştır, diğerinde ise biyofeedback tedavisi ile pelvik taban kas egzersizleri yapılan 30 müdahale grubu kadında yaşam kalitesinin arttığı saptanmıştır $(23,26)$.

Üi cinsel sağlık üzerine etkilerini araştıran 3 yüksek lisans tezinde ise Üi kadınlarda FSFI puan ortalaması ÜI olmayan kadınlara göre daha düşük bulunduğu cinsel fonksiyonların olumsuz yönde etkilendiği belirtilmiştir $(19,21,31)$.

Üriner inkontinansın depresyon ve ruhsal durumla ilişkisini inceleyen iki yüksek lisans tezinde; Üi deneyimleyen 
Tablo 1. Yüksek lisans tezlerinin incelenmesi

\begin{tabular}{|c|c|c|c|c|}
\hline Yazarı/ Yılı & Amaç & $\begin{array}{l}\text { Çalışmanın } \\
\text { Tipi }\end{array}$ & $\begin{array}{l}\text { Örneklem } \\
\text { Sayısı }\end{array}$ & Sonuç \\
\hline $\begin{array}{l}\text { Semra Kocagöz }{ }^{(17)} \\
2001\end{array}$ & $\begin{array}{l}\text { Kadınlarda stres Üi yaygınlığı ve } \\
\text { bunu etkileyen faktörlerin belirlenmesi }\end{array}$ & $\begin{array}{l}\text { Tanımlayıcı } \\
\text { tipte }\end{array}$ & 240 kadın & $\begin{array}{l}\text { Kadınların \%41.7'sinde stres Üi olduğu ve yaş, } \\
\text { gebelikte idrar kaçırma şikayeti, geçmişte stres } \\
\text { Üỉ öyküsünün, stres Üi gelişmesi üzerinde direkt } \\
\text { etkisinin olduğu saptanmıştır }\end{array}$ \\
\hline $\begin{array}{l}\text { Gülşah Kök(18) } \\
2005\end{array}$ & $\begin{array}{l}\text { Kadınlarda Üi bulguları yaşayanları } \\
\text { saptamak ve bu bulguların sosyal } \\
\text { yaşantılarına etkilerini saptamak }\end{array}$ & $\begin{array}{l}\text { Tanımlayıcı } \\
\text { tipte }\end{array}$ & $\begin{array}{l}20 \text { yaş üstü doğum } \\
\text { yapmış } 229 \text { kadın }\end{array}$ & $\begin{array}{l}\text { Kadınların \%37'sinde Üi bulguları saptanmış ve } \\
\text { Miks tip Üi bulguları olan kadınlarda yaşantıarının } \\
\text { psikolojik yönden en yüksek düzeyde etkilendiği } \\
\text { saptanmıştır. }\end{array}$ \\
\hline $\begin{array}{l}\text { Çiğdem Döndar }{ }^{(19)} \\
2006\end{array}$ & $\begin{array}{l}\text { Üi kadın cinsel sağlığı ve yaşam kalitesi } \\
\text { üzerine etkisini belirlemek }\end{array}$ & $\begin{array}{l}\text { Tanımlayıcı } \\
\text { tipte }\end{array}$ & $\begin{array}{l}80 \text { Üi olan kadın } \\
80 \text { Üi olmayan } \\
\text { kadın }\end{array}$ & $\begin{array}{l}\text { Üi kadın cinsel fonksiyonlarını ve yaşam kalitesini } \\
\text { olumsuz yönde etkilediği saptanmıştır }\end{array}$ \\
\hline $\begin{array}{l}\text { Hatice Acar Bektaş } \\
2007\end{array}$ & $\begin{array}{l}15 \text { yaş üstü, evli ve doğum yapmış } \\
\text { kadınlarda stres Üi yaygınlığı ile ilişkili } \\
\text { faktörlerin saptanması }\end{array}$ & $\begin{array}{l}\text { Kesitsel } \\
\text { tipte }\end{array}$ & $\begin{array}{l}15 \text { yaş üstü } \\
800 \text { kadın }\end{array}$ & $\begin{array}{l}\text { Stres Üi prevelansı \%20.1 (201/800) olarak } \\
\text { saptanmış ve yaş, eğitim seviyesi, gebelik } \\
\text { sayısı, parite ve beden kitle indeksi (BKI) arttıkça } \\
\text { stres Üi sıkıı̆ının da artı̆ı̆ı saptanmıştır. }\end{array}$ \\
\hline $\begin{array}{l}\text { Emine Özdemir(21) } \\
2009\end{array}$ & $\begin{array}{l}20 \text { yaş ve üzeri evli kadınlarda Üi } \\
\text { prevalansını, yaşam kalitesi ve cinsel } \\
\text { fonksiyon durumuna etkisini belirlemek }\end{array}$ & $\begin{array}{l}\text { Tanımlayıcı } \\
\text { tipte }\end{array}$ & $\begin{array}{l}20 \text { yaş üstü evli } \\
610 \text { kadın }\end{array}$ & $\begin{array}{l}\text { Kadınların \%22.6'sında Üi olduğu ve Üi kadınların } \\
\text { yaşam kalitesi ve cinsel fonksiyon durumlarını } \\
\text { olumsuz etkilediği saptanmıştır. }\end{array}$ \\
\hline $\begin{array}{l}\text { Gönül Akgün(22) } \\
2009\end{array}$ & $\begin{array}{l}40 \text { yaş üstü kadınlarda Üi görülme } \\
\text { sıklığını ve bu sorunu yaşayan kadınların } \\
\text { yaşam kalitelerinin hangi düzeyde } \\
\text { etkilendiğini belirlemek }\end{array}$ & $\begin{array}{l}\text { Tanımlayıcı } \\
\text { tipte }\end{array}$ & $\begin{array}{l}40 \text { yaş üstü } \\
435 \text { kadın }\end{array}$ & $\begin{array}{l}40 \text { yas üstü kadın populasyonunda Üi prevalansı } \\
\% 48.3 \text { olduğu ve Üi kadınların yasam kalitelerinin } \\
\text { çok fazla etkilenmediği saptanmıştır. }\end{array}$ \\
\hline $\begin{array}{l}\text { Naile Akşit Akıncl(23) } \\
2009\end{array}$ & $\begin{array}{l}\text { Stres Üi tanısı alan kadınların yaşam } \\
\text { kalitesini yükseltmek amaçlı verilen } \\
\text { pelvik taban kas egzersizleri eğitimin } \\
\text { etkinliğini değerlendirmek }\end{array}$ & $\begin{array}{l}\text { Prospektif } \\
\text { yarı deneysel } \\
\quad \text { tipte }\end{array}$ & 36 kadın & $\begin{array}{l}\text { Stres Üi tanısı alan kadınlara verilen eğitimin yaşam } \\
\text { kalitelerini arttırdığını saptanmıştır }\end{array}$ \\
\hline $\begin{array}{l}\text { Behice Nas Acar }{ }^{(24)} \\
2010\end{array}$ & $\begin{array}{l}\text { Üi olan } 65 \text { yaş ve üstü kadınlarda yaşam } \\
\text { kalitesi ve depresyon arasındaki ilişkinin } \\
\text { belirlenmesi }\end{array}$ & $\begin{array}{l}\text { Tanımlayıcı } \\
\text { tipte }\end{array}$ & $\begin{array}{l}65 \text { yaş ve } \\
\text { üzeri } 124 \text { kadın }\end{array}$ & $\begin{array}{l}\text { Üi olan yaşlı kadınların yaşam kalitesi düştükçe } \\
\text { depresyon belirtilerinin artığı belirlenmiştir. } \\
\text { Hastaların yaşam kalitesi ve depresyon puanlarını } \\
\text { eğitim durumu, gelir düzeyi, kronik hastalık varlığı, } \\
\text { oturulan konutun tipi ve doğum sayısının etkilediği } \\
\text { saptanmışıı. }\end{array}$ \\
\hline $\begin{array}{l}\text { Meryem Karasaç }{ }^{(25)} \\
2011\end{array}$ & $\begin{array}{l}\text { Doğum yapmış genç kadınlarda Üi } \\
\text { gelişmesinin obezite ve doğum sayısı ile } \\
\text { ilişkisinin saptanması }\end{array}$ & $\begin{array}{l}\text { Tanımlayıcı } \\
\text { tipte }\end{array}$ & $\begin{array}{c}40 \text { yaş ve } \\
\text { altı } 250 \text { kadın }\end{array}$ & $\begin{array}{l}\text { Normal vajinal doğum yapmış } 40 \text { yaş altı kadınların } \\
\text { \%34,8'inde Üi saptanmış ve kadınlarda BKI ve } \\
\text { doğum sayısı arttıkça Üil prevalansının arttığı } \\
\text { saptanmıştır. }\end{array}$ \\
\hline $\begin{array}{l}\text { Seda İlgün } \\
2011\end{array}$ & $\begin{array}{l}\text { Üi olan hastalarda biyofeedback ile } \\
\text { yapılan pelvik taban kas egzersizinin } \\
\text { inkontinans ve yaşam kalitesi üzerine } \\
\text { etkisini incelemek }\end{array}$ & $\begin{array}{l}\text { Deneysel } \\
\text { tipte }\end{array}$ & $\begin{array}{l}30 \text { müdahale } \\
30 \text { kontrol grubu } \\
\text { kadın }\end{array}$ & $\begin{array}{l}\text { Biyofeedback ile yapılan pelvik taban kas } \\
\text { egzersizinin Üi tedavisinde etkili olduğu ve yaşam } \\
\text { kalitesini yükselttiği saptanmıştır. }\end{array}$ \\
\hline $\begin{array}{l}\text { Münevver Özcan(27) } \\
2012\end{array}$ & $\begin{array}{l}\text { Üi olan } 65 \text { yaş ve üzeri } \\
\text { kadınlara verilen Kegel egzersizine ilişkin } \\
\text { bilgilendirmenin değerlendirilmesi }\end{array}$ & $\begin{array}{l}\text { Müdahale } \\
\text { çalışması }\end{array}$ & $\begin{array}{l}65 \text { yaş ve } \\
\text { üzeri } 31 \text { kadın }\end{array}$ & $\begin{array}{l}\text { Hastaların \% } 35.5 \text { 'inin } \\
\text { Kegel egzersizlerini her gün düzenli olarak yaptıkları } \\
\text { belirlenmiştir. }\end{array}$ \\
\hline $\begin{array}{l}\text { Sevda Demir(28) } \\
2012\end{array}$ & $\begin{array}{l}\text { Üi olan kadınlarda yaşam kalitesinin } \\
\text { etkilenme durumunu ve kadınların sağılı } \\
\text { arama davranışlarını belirlemek }\end{array}$ & $\begin{array}{l}\text { Tanımlayıcı } \\
\text { tipte }\end{array}$ & $\begin{array}{l}20 \text { yaş ve üzeri } \\
292 \text { kadın }\end{array}$ & $\begin{array}{l}\text { Kadınların yarısından fazlası yaklaşık } 3 \text { yııdır Üi } \\
\text { sorunu yaşamasına ve yaşam kalitelerinin olumsuz } \\
\text { etkilenmesine karşın doktora başvurma oranı düşük } \\
\text { olduğu saptanmıştır. }\end{array}$ \\
\hline $\begin{array}{l}\text { Tuba Demire|(29) } \\
2012\end{array}$ & $\begin{array}{l}\text { Evde yaşayan } 65 \text { yaş ve üzeri kadınlarda } \\
\text { Üi-Fi görülme sıklığı, risk faktörleri ve } \\
\text { Üil-Fi'nin yaşam kalitesi ile ilişkisini } \\
\text { belirlemek }\end{array}$ & $\begin{array}{l}\text { Kesitsel } \\
\text { tipte }\end{array}$ & $\begin{array}{l}65 \text { yaş ve } \\
\text { üzeri } 268 \text { kadın }\end{array}$ & $\begin{array}{l}\text { Üi prevalansı \%47.8 olduğu saptanmışıı. İleri yaşta, } \\
\text { ekonomik durumu kötü, doğum sayısı 1-2, çoğul } \\
\text { gebeliği, mesane prolapsusu, üç ve üzerinde kronik } \\
\text { hastalı̆ı ve ilaç kullanımı olanlarda Üi daha fazla } \\
\text { görüldüğü saptanmıştır. Üi olan kadınlarda yaşam } \\
\text { kalitesi puanın olumsuz yönde etkilendiği saptanmıştır. }\end{array}$ \\
\hline
\end{tabular}


Tablo 1. Yüksek lisans tezlerinin incelenmesi (Devamı)

\begin{tabular}{|c|c|c|c|c|}
\hline $\begin{array}{l}\text { Neriman Güdücü(31) } \\
2014\end{array}$ & $\begin{array}{l}\text { Üi yaşam kalitesine ve dini yaşama } \\
\text { etkisini, tedavi öncesi-sonrası dönemde } \\
\text { objektif ve subjektif parametrelerin } \\
\text { karşılaştırıması } \\
\text { Üi hastaların ruhsal durumlarının ve cinsel } \\
\text { fonksiyonlarının değerlendirilmesi }\end{array}$ & $\begin{array}{l}\text { Tanımlayıcı } \\
\text { tipte }\end{array}$ & $\begin{array}{l}20 \text { yaş ve } \\
\text { üstü } 300 \text { hasta }\end{array}$ & $\begin{array}{l}\text { Üi kadınların (\%50.8) günlük yaşam aktivitelerini } \\
\text { ciddi ölçüde etkilediği, (\%70.3) dini ibadetlerinin } \\
\text { kısıtlandığı ve ped ağırığı ile yaşam kalitesi } \\
\text { değerleri arasında negatif yönde bir ilişkinin olduğu } \\
\text { saptanmıştır. } \\
\text { Kadınların cinsel işlev fonksiyonlarında bozulma } \\
\text { arttıkça, anksiyete ve depresyon görülme riskinde } \\
\text { ve ruhsal belirti düzeylerinde artış olduğu; } \\
\text { anksiyete ve depresyon puanları arttıkça ise, diğer } \\
\text { tüm ruhsal belirti düzeylerinde de artış olduğu } \\
\text { belirlenmiştir. }\end{array}$ \\
\hline $\begin{array}{l}\text { Şeyma Aksu Sucuoğlu(32) } \\
2014\end{array}$ & $\begin{array}{l}\text { Üi'ın genç kızlarda görülme durumu, } \\
\text { tipleri, risk faktörleri ve yaşam kalitesi } \\
\text { üzerine etkilerini incelemek }\end{array}$ & $\begin{array}{l}\text { Tanımlayıcı } \\
\text { tipte }\end{array}$ & $\begin{array}{l}15-24 \text { yaş arası } \\
726 \mathrm{kız} \text { öğrenci }\end{array}$ & $\begin{array}{l}\text { Üi prevalansı \% } 17.6 \text { olarak bulunmuştur. } \\
\text { İnkontinans tipleri olarak \%8.9 stres, } \% 5.6 \text { urge } \\
\text { ve \%3.0'nın da miks tip inkontinans yaşadıkları } \\
\text { belirlenmiş ve Üi görülen öğrencilerde yaşam } \\
\text { kalitesinin daha düşük olduğu saptanmıştır. }\end{array}$ \\
\hline $\begin{array}{l}\text { Yeter Akkuş(33) } \\
2014\end{array}$ & $\begin{array}{l}18 \text { yaş üstü kadınlarda Üi sıkıı̆ı, } \\
\text { tipi, şiddeti, risk faktörleri ve yaşam } \\
\text { kalitelerine olan etkisini belirlemek }\end{array}$ & $\begin{array}{l}\text { Tanımlayıcı } \\
\text { tipte }\end{array}$ & $\begin{array}{l}18 \text { yaş ve } \\
\text { üstü } 150 \text { kadın }\end{array}$ & $\begin{array}{l}\text { Üi prevelansının \%86.7 olduğu ve \%59.2 ile miks } \\
\text { tipin en yüksek oranda görüldüğü saptanmıştı. Yaş, } \\
\text { gebelik sayısı, parite, beden kitle indeksi, menopoz, } \\
\text { doğum şekli, prolapsus ve sigara kullanımının Üi } \\
\text { riskini artırdığı ve Üi görülen kadınlarda yaşam } \\
\text { kalitesinin olumsuz etkilendiği saptanmıştı. }\end{array}$ \\
\hline $\begin{array}{l}\text { Sinem Göral(34) } \\
2014\end{array}$ & $\begin{array}{l}\text { Akdeniz Bölgesinde yer alan } \\
\text { huzurevlerinde yaşayan kadınlarda ÜI'ın } \\
\text { yaşam kalitesi üzerine etkisini belirlemek }\end{array}$ & $\begin{array}{l}\text { Tanımlayıcı } \\
\text { tipte }\end{array}$ & $\begin{array}{l}\text { 65- } 92 \text { yaşları } \\
\text { arasında Üi olan } \\
95 \text { kadın }\end{array}$ & $\begin{array}{l}\text { En fazla nokturnal inkontinansı olan kadınların } \\
\text { yaşam kalitesinin olumsuz etkilendiği saptanmıştır. }\end{array}$ \\
\hline $\begin{array}{l}\text { Hande Demirtaş}{ }^{(35)} \\
2015\end{array}$ & $\begin{array}{l}\text { Yaşlı bireylerde üriner } \\
\text { inkontinans, geriatrik depresyon ve } \\
\text { yalnızlık arasındaki ilişkinin belirlenmesi }\end{array}$ & $\begin{array}{l}\text { Tanımlayıcı } \\
\text { tipte }\end{array}$ & $\begin{array}{l}200 \text { yaşlı } \\
\text { (119Kadın, } 81 \\
\text { Erkek) }\end{array}$ & $\begin{array}{l}\text { Yaşlı bireylerde üriner inkontinans ile geriatrik } \\
\text { depresyon arasında pozitif yönde zayıf bir ilişki } \\
\text { saptanmıştır }\end{array}$ \\
\hline $\begin{array}{l}\text { Zeliha Aydın (36) } \\
2015\end{array}$ & $\begin{array}{l}35 \text { yaş üstü kadınlarda üriner inkontinans } \\
\text { görülme sıklığı ve farkındalık durumlarını } \\
\text { değerlendirmek }\end{array}$ & $\begin{array}{l}\text { Tanımlayıcı } \\
\text { ve kesitsel } \\
\text { tipte }\end{array}$ & $\begin{array}{l}35 \text { yaş üstü } \\
300 \text { kadın }\end{array}$ & $\begin{array}{l}\text { Hastaların \%48'inin ( } n=144 \text { ) idrar kaçırdığı, uzun } \\
\text { süre Üİ yaşamalarına rağmen sağlık kuruluşuna } \\
\text { başvurma oranının düşǚk olduğu,Ül'ın öneminin } \\
\text { farkında olmadıkları ve önemsemedikleri } \\
\text { saptanmıştır. }\end{array}$ \\
\hline $\begin{array}{l}\text { Özge Öz } \\
2016\end{array}$ & $\begin{array}{l}\text { Üi kadınların kullandıkları tamamlayıcı } \\
\text { alternatif tedavi (TAT) yöntemleri, yaşam } \\
\text { kalitesi ve benlik saygısı arasındaki ilişkiyi } \\
\text { değerlendirmek }\end{array}$ & $\begin{array}{l}\text { Tanımlayıcı } \\
\text { tipte }\end{array}$ & $\begin{array}{l}18 \text { yaş ve üzeri } \\
\text { üi şikayeti olan } \\
394 \text { kadın }\end{array}$ & $\begin{array}{l}\text { Kadınların kullandıkları TAT yöntemi sıklığı } \\
\text { \%33'tür. Üriner inkontiananslı kadınların King } \\
\text { Sağlık Anketi alt boyutları ve benlik saygısı ile } \\
\text { yaş, BKI, eğitim durumu, idrar kaçırma sıkığı, } \\
\text { üriner inkontinans türü, kronik hastalık varlığı ve } \\
\text { tamamlayıcı ve alternatif tedavi yöntemi kullanma } \\
\text { durumları arasındaki fark istatistiki olarak anlamlı } \\
\text { bulunmuştur. }\end{array}$ \\
\hline $\begin{array}{l}\text { Nazlı Baykuş(38) } \\
2016\end{array}$ & $\begin{array}{l}18 \text { yaş ve üzeri kadınlarda üriner } \\
\text { inkontinans sıkığını ve etkileyen faktörleri } \\
\text { belirlemek }\end{array}$ & $\begin{array}{l}\text { Tanımlayıcı } \\
\text { tipte }\end{array}$ & $\begin{array}{l}18 \text { yaş üstü } \\
1200 \text { kadın }\end{array}$ & $\begin{array}{l}\text { Üi görülme oranı \% } 26.3 \text { olarak belirtilmiştir. Üi'ın } \\
\text { yaş ve BKi ye parelel olarak artığı, uzun süreli } \\
\text { konstipasyon yaşayan, uzun süreli iYE geçiren, } \\
\text { kronik hastalığı olan, ailesinde Üi öyküsü olan, } \\
\text { menopoz döneminde olan, gebelik, düşük ve } \\
\text { doğum sayısı yüksek olan, vajinal doğum yapan } \\
\text { kadınlarda Üï oranı yüksek saptanmıştır. }\end{array}$ \\
\hline $\begin{array}{l}\text { Saliha Gök }{ }^{(39)} \\
2016\end{array}$ & $\begin{array}{l}\text { Diyabetik kadınlarda üriner semptomları } \\
\text { ve inkontinansın yaşam kalitesine etkisini } \\
\text { belirlemek }\end{array}$ & $\begin{array}{l}\text { Tanımlayıcı } \\
\text { ve kesitsel } \\
\text { tipte }\end{array}$ & $\begin{array}{l}\text { Diyabet tanısı olan } \\
383 \text { gönüllü kadın }\end{array}$ & $\begin{array}{l}\text { Diabetik kadınların \%43,6'sında ( } \mathrm{n}=167 \text { ) idrar } \\
\text { kaçırma şikayeti olduğu saptanmıştır. Çok } \\
\text { değişkenli lojistik regresyon } \\
\text { analizi sonucunda, diyabetik kadınlarda inkontinans } \\
\text { için en önemli risk faktörlerinin; } \\
\text { albuminüri, akciger hastalıgı, BKı > } 30 \text { olması, } \\
\text { uzun/müdahaleli dogum öyküsü, retinopati, } \\
\text { nefropati, günde >3 bardak çay içme, yılda >2 kez } \\
\text { genital enfeksiyon geçirme ve HbA1c düzeyindeki } \\
\text { artış olduğu saptanmışır. }\end{array}$ \\
\hline
\end{tabular}


65 yaş üstü kadınlarda depresyon puanlarının daha yüksek olduğu, Üi olan 20 yaş üstü kadınlarda ise cinsel işlev fonksiyonlarında bozulma arttıkça, anksiyete ve depresyon görülme riskinde ve ruhsal belirti düzeylerinde artış olduğu belirtilmiştir $(24,31)$.

Özcan'ın (2012) çalışmasında ise Üi deneyimleyen 65 yaş üstü kadınlara öğretilen kegel egzersizlerini kadınların \%35.5'i her gün düzenli olarak yaptıkları saptanmıştır (27).

Tablo 2'de görüldüğü gibi doktora tezlerinden ilk çalışma, 20 yaş üstü 625 kadında Üi prevalansı \%25.8 olduğu ve Üi görülen kadınlarda yaşam kalitesinin olumsuz etkilendiği saptanmıştır (40).
Üi semptomları olan gebelerde, gebelik ve postpartum dönemde uygulanan pelvik taban kas egzersizlerinin bu semptomların tedavisi ve önlenmesindeki etkinliğini araştırmak amacıyla yapılan deneysel tipte ki çalışmada gebelikte ve postpartum dönemde pelvik taban kas egzersizlerinin, pelvik taban kas gücünü artırdığı ve Üi'ın önlenmesi ve tedavisinde oldukça etkili olduğu saptanmıştır (41).

65 yaş ve üzeri Üi şikâyeti olan kadınlarda, mesane eğitimi ve Kegel egzersizlerinin etkinliğinin incelendiğindi deneysel prospektif tipteki çalışmada mesane eğitimi ve pelvik taban kas egzersizlerinin üriner şikayetleri azaltmada etkili olduğu saptanmıştır (42).

Tablo 2. Doktora Tezlerinin incelenmesi

\begin{tabular}{|c|c|c|c|c|}
\hline Yazarı/ Yılı & Amaç & $\begin{array}{c}\text { Çalışmanın } \\
\text { Tipi }\end{array}$ & $\begin{array}{c}\text { Örneklem } \\
\text { Sayısı }\end{array}$ & Sonuç \\
\hline $\begin{array}{l}\text { Nebahat Özedoğan }{ }^{(40)} \\
2003\end{array}$ & $\begin{array}{l}20 \text { yaş ve üstü kadınlarda üriner } \\
\text { inkontinansın prevalansını, risk faktörlerini } \\
\text { ve yaşam kalitesi üzerine etkisini } \\
\text { belirlemek }\end{array}$ & $\begin{array}{l}\text { Kesitsel } \\
\text { tipte }\end{array}$ & $\begin{array}{c}20 \text { yaş ve üstü } 625 \\
\text { kadın }\end{array}$ & $\begin{array}{l}\text { Üriner inkontinansın prevalansı \%25.8 ve Üi } \\
\text { görülen kadınlarda yaşam kalitesinin olumsuz } \\
\text { etkilendiği saptanmıştı. }\end{array}$ \\
\hline $\begin{array}{l}\text { Ayten Dinç } \\
2004\end{array}$ & $\begin{array}{l}\text { Üi şikayeti olan gebelerde, gebelik ve } \\
\text { postpartum dönemde uygulanan pelvik } \\
\text { taban kas egzersizlerinin bu şikayetin } \\
\text { tedavisi ve önlenmesindeki etkinliğini } \\
\text { araştırmak }\end{array}$ & $\begin{array}{l}\text { Deneysel } \\
\text { tipte }\end{array}$ & 80 gebe & $\begin{array}{l}\text { Gebelikte ve postpartum dönemde uygulanan } \\
\text { pelvik taban kas egzersizlerinin, pelvik taban kas } \\
\text { gücünü artırmada ve Üi önlenmesi ve tedavisinde } \\
\text { oldukça etkili olduğu saptanmıştır. }\end{array}$ \\
\hline $\begin{array}{l}\text { Ergül Aslann }{ }^{(42)} \\
2005\end{array}$ & $\begin{array}{l}65 \text { yaş ve üzeri üriner şikayetleri olan } \\
\text { kadınlarda, mesane eğitimi ve Kegel } \\
\text { egzersizlerinin etkinliğini belirlemek }\end{array}$ & $\begin{array}{l}\text { Deneysel } \\
\text { prospektif } \\
\text { tipte }\end{array}$ & $\begin{array}{l}25 \text { vaka } 25 \text { kontrol } \\
\text { grubu kadın }\end{array}$ & $\begin{array}{l}\text { İleri yaştaki kadınlara uygulanan mesane } \\
\text { eğitimi ve pelvik taban kas egzersizlerinin üriner } \\
\text { şikayetleri azaltmada etkili olduğu saptanmıştır. }\end{array}$ \\
\hline $\begin{array}{l}\text { Dilek Sarı(43) } \\
2007\end{array}$ & $\begin{array}{l}\text { Stres Üi ya da karışık tipte Üi tanısı alan } \\
\text { kadınlarda pelvik taban kas egzersizinin } \\
\text { Üi ve yaşam kalitesi üzerine etkisini } \\
\text { incelemek }\end{array}$ & $\begin{array}{l}\text { Deneysel } \\
\text { Tipte }\end{array}$ & $\begin{array}{l}\text { Çalışma grubu 17, } \\
\text { kontrol grubu } 17 \text { kadın }\end{array}$ & $\begin{array}{l}\text { Pelvik taban kas egzersizinin stres Üi ya da } \\
\text { karısık tipte Üi tanısı alan hastalarda kaçııılan } \\
\text { idrar miktarını, sayısını, sıkıı̆ını azaltmada, pelvik } \\
\text { taban kas gücü ve yaşam kalitesini arttırmada } \\
\text { etkin olduğu bulunmuştur. }\end{array}$ \\
\hline $\begin{array}{l}\text { Semra Kocaöz }{ }^{(44)} \\
2007\end{array}$ & $\begin{array}{l}\text { Gebeliğin 14-20. haftasından itibaren } \\
\text { stres Üi önlemeye yönelik uygulanan } \\
\text { pelvik taban kas egzersizlerinin doğum } \\
\text { sonrası 12. haftadaki etkinliğini incelemek }\end{array}$ & $\begin{array}{l}\text { Prospektif } \\
\text { müdahale } \\
\text { çalışması }\end{array}$ & $\begin{array}{l}52 \text { müdahale ve } \\
50 \text { kontrol grubu gebe }\end{array}$ & $\begin{array}{l}\text { Pelvik taban kas egzersizlerinin gebelik ve doğum } \\
\text { sonu donemdeki stres Ül'ın önlenmesinde etkili } \\
\text { olduğu saptanmıştır. }\end{array}$ \\
\hline $\begin{array}{l}\text { Hale Uyar Hazar }{ }^{(45)} \\
2008\end{array}$ & $\begin{array}{l}\text { Üi olan romatoid artritli kadınlarda } \\
\text { mesane eğitimi ve Kegel egzersizinin } \\
\text { etkinliğini belirlemek }\end{array}$ & $\begin{array}{l}\text { Tanımlayıcı, } \\
\text { deneysel ve } \\
\text { prospektif }\end{array}$ & $\begin{array}{l}\text { Mesane eğitimi verilen } \\
30, \text { kegel egzersizi } \\
\text { yaptırlan } 30 \\
\text { kontrol grubu } 30\end{array}$ & $\begin{array}{l}\text { Üi olan romatoid artritli kadınlarda mesane eğitimi } \\
\text { ve Kegel egzersizinin üriner yakınmaları azaltmada } \\
\text { ve pelvis tabanındaki kasların gücünü artırmada } \\
\text { etkili olduğunu saptanmışıı }\end{array}$ \\
\hline $\begin{array}{l}\text { Neriman Zengin }{ }^{(46)} \\
2008\end{array}$ & $\begin{array}{l}\text { Üi olan kadınlarda hemşirelik eğitimi ve } \\
\text { davranışsal tedavinin konfor, pelvik taban } \\
\text { kas egzersizi öz-etkililik algısı ve yaşam } \\
\text { kalitesine etkisini incelemek }\end{array}$ & $\begin{array}{l}\text { Deneysel } \\
\text { Tipte }\end{array}$ & $\begin{array}{c}\text { Üi olan } 30 \text { yaş ve } \\
\text { üzeri } 30 \text { kadın }\end{array}$ & $\begin{array}{l}\text { Üi olan kadınlarda hemşirelik eğitimi ve } \\
\text { davranışsal tedavi konforun, öz etkililik algısının } \\
\text { ve yasam kalitesinin artmasında etkili olduğu } \\
\text { saptanmıştır }\end{array}$ \\
\hline $\begin{array}{l}\text { Şenay Topuz } \\
2011\end{array}$ & $\begin{array}{l}\text { Ül'ı olan kadınlara uygulanan kegel } \\
\text { egzersizlerinin, kadın cinsel } \\
\text { doyum üzerine etkilerini belirlemek }\end{array}$ & $\begin{array}{l}\text { Deneysel } \\
\text { Tipte }\end{array}$ & $\begin{array}{l}\text { Stres üriner inkontinans } \\
\text { tanısı almıs } 30 \text { kegel } \\
\text { egzersizi grubu ve } \\
30 \text { kontrol grubu kadın }\end{array}$ & $\begin{array}{l}\text { Çalısmanın sonucunda kegel egzersizlerinin } \\
\text { kadınların cinsel doyumları üzerine olumlu etki } \\
\text { gösterdiği belirtilmiştir. }\end{array}$ \\
\hline $\begin{array}{l}\text { Dilek Bilgiç Çelik }{ }^{(48)} \\
2012\end{array}$ & $\begin{array}{l}\text { Üi ve / veya pelvik organ prolapsus } \\
\text { cerrahisi uygulanan kadınların yaşam } \\
\text { kaliteleri ve cinsel işlevlerinin nasıl } \\
\text { etkilendiğini belirlemek }\end{array}$ & $\begin{array}{l}\text { Tanımlayıcı, } \\
\text { prospektif } \\
\text { tipte }\end{array}$ & $\begin{array}{l}\text { Üi } 42 \text { hasta, POP } 35 \\
\text { hasta ve Ül ve } \\
\text { POP } 39 \text { hasta }\end{array}$ & $\begin{array}{l}\text { Ül ve/veya POP cerrahisi sonrası kadınların } \\
\text { postoperatif } 6 \text {. ayda yaşam kaliteleri ve } \\
\text { cinsel fonksiyonlarının olumlu yönde değiştiği } \\
\text { saptanmışır. }\end{array}$ \\
\hline
\end{tabular}


Üi tanısı alan kadınlarda pelvik taban kas egzersizinin Üí ve yaşam kalitesi üzerine etkisini incelemek amacıyla deneysel tipte yapılan çalışmada deney grubunda pelvik taban kas egzersizinin kaçırılan idrar miktarını, sayısını, sıklığını azaltmada, pelvik taban kas gücünü ve yaşam kalitesini arttırmada etkin olduğu saptanmıştır (43).

Gebeliğin 14-20. haftasından itibaren stres Ül'i önlenmeye yönelik uygulanan pelvik taban kas egzersizlerinin doğum sonrası 12. haftadaki etkinliğini inceleyen prospektif müdahale çalışmasında pelvik taban kas egzersizlerinin gebelik ve doğum sonu dönemdeki stres Üi'in önlenmesinde etkili olduğu saptanmıştır (44).

Üi olan romatoid artritli kadınlarda mesane eğitimi ve Kegel egzersizinin etkinliğini belirleyen tanımlayıcı, deneysel ve prospektif tipteki çalışmada mesane eğitimi ve Kegel egzersizinin üriner yakınmaları azaltmada ve pelvis tabanındaki kasların gücünü artırmada etkili olduğunu saptanmıştır (45).

Üi olan kadınlarda hemşirelik eğitimi ve davranışsal tedavinin konfor, pelvik taban kas egzersizi, öz-etkililik algısı ve yaşam kalitesine etkisini inceleyen deneysel tipteki çalışmada Üi olan kadınlarda hemşirelik eğitimi ve davranışsal tedavi konforun, öz etkililik algısının ve yaşam kalitesinin artmasında etkili olduğu saptanmıştır (46).

Stres üriner inkontinansı (SÜi) olan kadınlara uygulanan kegel egzersizlerinin, kadın cinsel doyum üzerine etkilerini belirlemek amacıyla yapılan deneysel tipteki doktora tezinde kegel egzersizleri yapılan kadınlarda cinsel doyumların olumlu yönde etkilendiği saptanmıştır (47).

Üi ve / veya pelvik organ prolapsus cerrahisi uygulanan kadınların yaşam kaliteleri ve cinsel işlevlerinin nasıl etkilendiğini inceleyen tanımlayıcı, prospektif tipte çalışmada Ül ve/veya POP cerrahisi sonrası kadınların postoperatif 6. ayda yaşam kaliteleri ve cinsel fonksiyonlarının olumlu yönde değiştiği saptanmıştır (48).

\section{Tartışma}

Üi ile ilgili yapılan bu sistematik derleme çalışmasında, yüksek lisans ve doktora tezlerinde tanımlayıcı, yarı deneysel ve deneysel çalışmaların yapıldığı görülmüştür. Farklı̈̈rneklem büyüklüklerinde ve farklı yaş grubu kadınlarda yapılan bu tezlerde, Üi'ın yaygın bir sağlık sorunu olduğu, bireylerin sosyal hayatını, yaşam kalitesini ve cinsel sağlığını olumsuz etkilediği belirtilmiştir.
Tanımlayıc olarak yapılan yüksek lisans ve doktora tezlerinde Üi prevalansının tüm yaş gruplarında \%22.6'dan \%86.7 arasında farklı oranlarda yaygın olarak görüldüğü bildirilmiştir $(18,21,22,25,29,33,40)$. Üi tiplerine göre ise yaş gruplarında farklııklar göstererek stres Ül, urge Üi ve miks tip inkontinansın da yaygın olarak görüldüğü bildirilmiştir $(17,20,29,32,33)$. Dünyada ve ülkemizde yapılan geniş toplum tabanlı prevalans çalışmalarında kadınlarda ortalama \%18 ile \%45 arasında Üi görüldüğü, bu oranların ilerleyen yaşla birlikte arttığı bildirilmekte$\operatorname{dir}(4,5,6,7,8,9,10,11)$. Incelenen yüksek lisans ve doktora tezlerinde ve dünyada ve ülkemizde yapılan diğer çalışmalarda Üi prevalanslarının birbirinden farklı oldukları görülmektedir. Bu prevalans farklılıkları çalışılan örneklem sayılarının farklı oluşundan, farklı yaş gruplarını kapsamasından ve örneklem grubunun hastane tabanlı ya da toplum tabanlı oluşundan kaynaklı olduğu düşünülmektedir.

Altı yüksek lisans tezinde Üi etkileyen faktörler araştırılmıştır. Bu tezlerde yaş, eğitim seviyesi, gebelik sayısı, doğum şekli, gebelikte idrar kaçırma şikâyeti varlığı, çoğul gebelik, BKi'nin artması, kötü ekonomik koşullar, kronik hastalık varlığı, menopoz, prolapsus varlığı ve sigara kullanan kişilerde Üi varlığının daha fazla görüldüğü saptanmıştır. Ayrıca başka bir çalışmada 15- 24 yaş arası kız öğrencilerde çocukluğunda tuvalet eğitimi sonrası geceleri idrar kaçırma problemi olan, sürekli idrar yolu enfeksiyonu yaşayan, idrarını tutma/erteleme alışkanlığına sahip olan ve sigara içen öğrenciler de Üi yaşama oranının yüksek olduğu saptanmıştır $(17,20,25,29,32,33)$. Dünyada ve ülkemizde yapılan çalışmalarda Üi gelişiminde; yaş, cinsiyet, ilk doğum yaşı, doğum şekli, doğum travması, menopoz, BKI'nin yüksek olması, sigara kullanımı, genetik faktörler, ırk, üriner enfeksiyon, perineal travma, histerektomi, geçirilmiş pelvik operasyonlar, östrojen eksikliği, diyabet gibi kronik hastalıklarla gelişen nörolojik hasarlar ve kognitif bozukluklar, alkol, kafein ve tütün kullanımı, düşük fiziksel aktivite, konstipasyon, psikososyal bozukluklar ve sosyal tuvalet alışkanlıkları gibi faktörlerin etkili olduğu belirtilmektedir $(5,7,8,9,10,11)$. Üriner inkontinanstan korunmak değiştirilemeyecek faktörlere (genetik yatkınlık, yaş vb. ) bağlı olduğu gibi yaşam biçiminde değişiklik sağlanarak pelvik kasları güçlendirmek ve dolayısıyla Üi'i korunmak mümkündür. Kontinans hemşireliği tarafından Üi etkileyen faktörlerin bilinmesi koruyucu sağlık hizmetleri kapsamında Üi sorununun gelişmesini önlemeye yönelik tedbirler alınması açısından önemlidir. Kontinans hemşireleri Üi gelişiminin önlenmesi için yeme alışkanlıkları, kilo kontrolü, sigara bırakma, egzersiz, bağırsak/mesane alışkanlıkları gibi yaşam tarzının değiştirilmesi gereken konularda bireye ve yakınlarına sağlığı korumaya ilişkin bilgi sunmada birincil konumdadır (49). 
Yüksek lisans tezlerinin 11 'inde ve Doktora tezlerinin ise birinde Ül'ın kadınların yaşam kalitelerini nasıl etkilediği araştırılmıştır. Üi olan farklı yaş grubunda ki kadınlarda farklı ölçeklerle yaşam kalitesinin ölçüldüğü tez çalışmalarında, kadınların yaşam kalitesinin olumsuz yönde etkilendiği bildirilmiştir $(18,19,21,22,24,28,29,30,32,33,34,40)$. "Algılanan yaşam koşullarından memnun olma derecesi" olarak tanımlanan yaşam kalitesinin Üi'ı olan kadınlarda olumsuz etkilendiği, Üi yaşama süresi arttıkça yaşam kalitesinin azaldığı ve bu sorunu daha sık yaşayanların yaşam kalitelerinin yaşamayanlara göre daha düşük olduğu yapılan çalışmalar ile bilinmektedir $(6,7,50)$. Üi sadece tıbbi bir sorun olmayıp aynı zamanda fiziksel, psikolojik, ekonomik ve sosyal iyilik hali olarak tanımlanan yaşam kalitesini de etkilediği bu çalışmada incelenen tezlerde ve yapılan diğer çalışmalarda saptanmıştır (50).

İncelenen tezlerde Üi kadınlarda yaşam kalitesini arttırmaya yönelik deneysel tipte yapılan 2 yüksek lisans tezi ve 2 doktora tezinde, pelvik taban kas gücünü arttıran pelvik taban kas egzersizlerinin Üi tedavisinde etkili olduğu ve yaşam kalitesini arttırdığı belirtilmiştir. Ayrıca Üi tanısı alan kadınlara verilen hemşirelik eğitimin yaşam kalitesinin artmasında etkili olduğu saptanmıştır $(23,26,43,46)$. Başka bir doktora tezinde Ül ve/veya POP cerrahisi sonrasının izlendiği prospektif tanımlayıcı çalışmada kadınların postoperatif 6 . ayda yaşam kaliteleri ve cinsel fonksiyonlarının olumlu yönde değiştiği belirtilmiştir (48). Kontinans hemşirelerinin, inkontinans sorununun çözümüne yönelik verilen hemşirelik eğitimleri ile pelvik taban kas egzersizleri ile üriner günlükler gibi evde bakım uygulamaları ile bakım kalitesinin yükselmesinde ve yaşam kalitesinin arttırılmasında etkin rol oynadıkları kanıtlanmıştır (12).

Üriner inkontinansın kadınların cinsel fonksiyonlarını olumsuz etkilediği 3 yüksek lisans tezinde belirtilmiştir $(19,21,31)$. Kadın cinsel sağlığını çeşitli derecelerde etkileyen üriner inkontinans sorununun psikolojik boyutunun etiyolojisinde, ilişki sırasında idrar kaçırma korkusu, kötü koku endişesi rol oynamaktadır (51). Patofizyolojisi tam olarak bilinmemesine rağmen Üi'ın cinsel fonksiyona etkisi bilinmektedir. Üi ve cinsel fonksiyon bozukluklarının birlikte görülme oranı dikkate alındığında Üi olan hastalarda cinsel fonksiyonun hemşireler tarafından mutlaka sorgulanmalıdır.

Güdücü'nün (2014) Yüksek lisans tezinde Üi'si olan 300 kadında cinsel işlev fonksiyonlarında bozulma arttıkça, anksiyete ve depresyon görülme riskinde ve ruhsal belirti düzeylerinde artış olduğu belirtilmiştir (31). Üi kadınlar ile farklı yöntemlerle yapılan pelvik taban kas egzersizleri ile pelvik taban kas gücünün arttığı ve bu durumun kadın cinsel işlev fonksiyonlarını olumlu yönde etkilediği belirtilmiştir $(52,53)$. Bu bilgiler ışığında Üi tedavisinin sağlanması ile cinsel işlev fonksiyonlarında da iyileşme olacağı ve kadında anksiyete, depresyon görülme riskinde azalma olacağı kanısındayız.

Bir yüksek lisans, 4 doktora tezinde pelvik taban kas egzersizleri ile pelvik taban kas gücünün artmasında ve Üi önlenmesi tedavisinde oldukça etkili olduğu saptanmıştır $(17,26,41,45,46)$. Benzer şekilde Dumoulin ve Hay-Smith (2010), cochraine veri tabanında yayınlanan sistematik derleme çalışmasında idrar kaçırma şikayeti olan kadınlarda, PTK egzersizi yapan grupta kontrol grubuna göre daha fazla iyileşme olduğu, kadınların yaş ortalaması düştükçe ve egzersiz programının süresi uzadıkça egzersizin iyileştirme oranında artma olduğu, PTK egzersizi stres tipi idrar kaçırmada, urge ve miks tipe göre daha etkili olduğu belirtilmiştir. En az üç ay süreyle PTK egzersizi yapan kadınlarda tedavinin etkisi daha fazla görülmüştür (54). Kontinans hemşireleri sağlığı koruma/geliştirme ve eğitimci rolleri ile tüm yaş grubu kadınlara, pelvik taban kas egzersizlerini öğreterek Üi'ın gelişmesini önlemede ve var olan Üi ın tedavisinde etkili olabilirler.

\section{Sonuç}

Üriner inkontinans, kadının benlik algısını ve saygısını, doğurganlığını, cinsel yaşamını ve aile yapısını etkilediğinden dolayı çok önemlidir. Bu nedenle Üi görülme sıklığını tespit etmek, risk faktörlerini belirlemek, nedenini araştırmak, Üi'dan korunma ve tedavide uygun stratejiler geliştirmek giderek daha büyük önem kazanmaktadır. Aynı zamanda Üi'li kadınların yaşamlarını kaliteli bir şekilde sürdürmeleri, tedavi ve bakım olanaklarından yararlanmaları temeldir. Bundan dolayı Üi'li kadınlara hizmet veren hemşirelerin kadının ihtiyacı olan tedavi ve bakımı iyi bilmesi, güncel bilgilere sahip olması ve bakımlarını bireye özgü planlaması gerektiğinden önemli sorumlulukları vardır. Toplumun, özellikle kadınların Üi konusunda bilgi düzeylerini arttırmak, destek olmak, yaşanılan sıkıntıları belirlemek ve en aza indirebilmek için hemşirelerin danışmanlık yapmaları önemlidir.

Üi her yaş grubu kadında yaygın bir şekilde görüldüğü yapılan çalışmalarla tanımlanmış olup yaşam kalitesini olumsuz etkilediği saptanmıştır. Deneysel çalışmalarla pelvik taban kas egzersizleri ile kas gücünün arttırıldığı ve yaşam kalitesini olumlu etkilediği belirtilmiştir. ÜI'nin korunması ve tedavisine yönelik hemşireler tarafından daha çok deneysel araştırmaların yapılması önerilmektedir 


\section{Kaynaklar}

1. Lapitan M, Carmela M. Epidemiology of Urinary Incontinence. In: Badlani G.H.,Davila G.W.,Michel, M.C. Rosette J.J.M.C.H. (eds). Continence Current Concepts and Treatment Strategies. London: Springer; 2009,3-13.

2. Abrams P, Cardozo L, Fall M, Griffiths D, Rosier P, Ulmsten U, et al. The standardization of terminology of lower urinary tract function: Report from the standardization sub-committee of the International Continence Society. Neurourol Urodyn. 2002;21:167-78. [CrossRef]

3. Esler R. Chapter 1 Introduction. Chan L.,Tse V. (eds). Multidisciplinary Care of Urinary Incontinence A Handbook for Health Professionals. London: Springer; 2013,1-5.

4. García-Pérez H, Harlow SD, Sampselle CM, Denman C. Measuring urinary incontinence in a population of women in northern Mexico: prevalence and severity. Int Urogynecol J 2013;24:847-54. [CrossRef]

5. Kirss F, Lang K, Toompere K, Veerus P. Prevalence and risk factors of urinary incontinence among Estonian postmenopausal women. Springerplus. 2013;2:524-31. [CrossRef]

6. Rebassa M, Taltavull JM, Gutiérrez C, et al. Urinary incontinence in Mallorcan women: prevalence and quality of life. Actas Urol Esp. 2013;37:354-61. [CrossRef]

7. Jokhio AH, Rizvi RM, Rizvi J, Macarthur C. Urinary incontinence in women in rural Pakistan: prevalence, severity, associated factors and impact on life. BJOG. 2013;120:180-6. [CrossRef]

8. Sensoy N, Dogan N, Ozek B, Karaaslan L. Urinary incontinence in women: prevalence rates, risk factors and impact on quality of life. Pak J Med Sci. 2013;29:818-22.

9. Dursun P, Dogan NU, Kolusari A, et al. Differences in geographical distribution and risk factors for urinary incontinence in Turkey: analysis of 6,473 women. Urollnt. 2014;92:209-14. [CrossRef]

10. Yalcin O, Timur S, Ozbas A, et al. Urinary incontinence prevalence and risk factors in women aged 20 and over in Malatya. Int J Urol Nurs 2011;5:65-72. [CrossRef]

11. Terzi H. Terzi R. Kale A. 18 yaş üstü kadınlarda üriner inkontinans sıklığı ve etkileyen faktörler. Ege Tıp Derg 2013;52:15-9.

12. DuMoulin MF, Hamers JP, Paulus A, Berendsen C, HalfensR.The role of the nurse in community continence care: a systematic review. Int J Nurs Stud 2005;42:479-92. [CrossRef]

13. Yeşiltepe Oskay Ü. Üriner inkontinansın önlenmesi ve kontinansın geliştirilmesi. In: Beji NK (ed). Kadınlarda Üriner İnkontinans ve Hemşirelik Yaklaşımı. İstanbul: İstanbul Üniversitesi yayınları; 2002,61-72.

14. Palmer M.H. Urinary incontinence quality Improvement in nursing homes: Where have we been? Where are we going? Urol Nurs 2008;28:439- 44.

15. Rantell, A. (2010). The role of continence nurse. In: Cardozo L, Dawid S. (eds). TextBook of Female Urology and Urogynecology. UK: Informa Health Care; 2008,388.

16. Carcio, H. Comprehensive continence care: the nurse practitioner's role. Adv Nurse Pract 2003;11:26- 36.

17. Kocagöz S. Etimesgut II nolu Sağlık Ocağı Bölgesi'ndeki kadınlarda stres üriner inkontinans yaygınlığı ve bunu etkileyen faktörlerin belirlenmesi (Yüksek Lisans Tezi). Ankara, Hacettepe Üniversitesi 2001.

18. Kök G. GATA kadın hastalıkları ve doğum polikliniğine başvuran kadınlarda üriner inkontinans görülme sıklığı ve sosyal yaşama etkisinin incelenmesi (Yüksek Lisans Tezi). Ankara, Gülhane Askeri Tıp Akademisi, 2005.

19. Döndar Ç. Üriner inkontinansın kadın cinsel fonksiyonları ve yaşam kalitesi üzerine etkisi (Yüksek Lisans Tezi). İstanbul, Marmara Üniversitesi, 2006.

20. Acar Bektaş H. Emek Sağlık Ocağı Bölgesi'nde yaşayan kadınlarda stres üriner inkontinans yaygınlığı ile ilişkili faktörlerin incelenmesi (Yüksek Lisans Tezi). Sivas Cumhuriyet Üniversitesi, 2007.
21. Özdemir E. Gülveren Sağlık Ocağı Bölgesi'nde 20 yaş ve üzeri evli kadınlarda üriner inkontinansın yaşam kalitesi ve cinsel fonksiyon üzerine etkisi (Yüksek Lisans Tezi). Eskişehir, Eskişehir Osmangazi Üniversitesi, 2009.

22. Akgün G. 40 yaş üzeri kadınlarda üriner inkontinansın görülme sıklığı ve yaşam kalitesi üzerine etkisinin belirlenmesi (Yüksek Lisans Tezi). Edirne, Trakya Üniversitesi, 2009.

23. Akşit Akıncı N. Stres üriner inkontinas tanısı alan kadınlara verilen eğitimin yaşam kalitesine etkisi (Yüksek Lisans Tezi). Ankara, Gazi Üniversitesi, 2009.

24. Nas Acar B. Üriner inkontinansı olan yaşlı kadınlarda yaşam kalitesi ve depresyon arasındaki ilişki (Yüksek Lisans Tezi). Mersin, Mersin Üniversitesi, 2010.

25. Karasaç M. Normal vajinal doğum yapmış genç kadınlarda obesite ve doğum sayısı ile üriner inkontinans arasındaki ilişkinin karşılaştııılması (Yüksek Lisans Tezi). Afyon, Afyon Kocatepe Üniversitesi, 2011.

26. İlgün S. Üriner inkontinansı olan hastalarda biyofeedback ile yapılan pelvik taban kas egzersizinin inkontinans ve yaşam kalitesi üzerine etkisi (Yüksek Lisans Tezi). Gaziantep, Gaziantep Üniversitesi, 2011.

27. Özcan M. Üriner inkontinansı olan 65 yaş üstü kadınlara verilen kegel egzersizine ilişkin bilgilendirmenin değerlendirilmesi (Yüksek Lisans Tezi). Ankara, Hacettepe Üniversitesi 2012.

28. Demir S. Üriner inkontinanslı kadınlarda yaşam kalitesi ve sağlık arama davranışı (Yüksek Lisans Tezi). İstanbul, Haliç Üniversitesi, 2012.

29. Demirel T. 65 yaş ve üzeri kadınlarda üriner - fekal inkontinansın yaygınlığı, risk faktörleri ve yaşam kalitesi (Yüksek Lisans Tezi). Konya, Selçuk Üniversitesi, 2012.

30. Kurul Ş. Üriner inkontinansın yaşam kalitesine etkisi, tedavi öncesi ve sonrası dönemde objektif ve sübjektif parametrelerin karşılaştırılması (Yüksek Lisans Tezi). Eskişehir, Eskişehir Osmangazi Üniversitesi, 2013.

31. Güdücü N. Üriner inkontinanslı hastaların ruhsal durumlarının ve cinsel fonksiyonlarının değerlendirilmesi (Yüksek Lisans Tezi). İstanbul, İstanbul Üniversitesi, 2014.

32. Aksu Sucuoğlu Ș. Genç kızlarda üriner inkontinans, risk faktörleri ve yaşam kaliteleri (Yüksek Lisans Tezi). İstanbul, Haliç Üniversitesi, 2014.

33. Akkuş Y. 18 yaş üstü kadınlarda üriner inkontinans sıklığı, tipi, şiddeti, risk faktörleri ve yaşam kalitesine etkisinin değerlendirilmesi (Yüksek Lisans Tezi). Ankara, Yıldırım Beyazıt Üniversitesi, 2014.

34. Göral S. Akdeniz Bölgesi huzurevlerinde yaşayan kadınlarda üriner inkontinans ve yaşam kalitesi (Yüksek Lisans Tezi). Antalya, Akdeniz Üniversitesi, 2014.

35. Demirtaş $H$. Yaşlılarda üriner inkontinans geriatrik depresyon ve yalnızlık arasındaki ilişkinin incelenmesi (Yüksek Lisans Tezi). Ankara, Yıldırım Beyazıt Üniversitesi, 2015.

36. Aydın Z. 35 yaş üstü kadınlarda üriner inkontinans görülme sıklığı ve farkındalık durumunun değerlendirilmesi (Yüksek Lisans Tezi). İstanbul, Haliç Üniversitesi, 2015.

37. Öz Ö. Üriner inkontinanslı kadınların kullandıkları alternatif yöntemler, yaşam kalitesi ve benlik saygısı arasındaki ilişki (Yüksek Lisans Tezi). Samsun, Ondokuz Mayıs Üniversitesi, 2016.

38. Baykuş N. 18 yaş üstü kadınlarda üriner inkontinans görülme sıklığı ve etkileyen faktörler (Yüksek Lisans Tezi). İzmir, Şifa Üniversitesi, 2016.

39. Gök S. Diyabetik kadınlarda üriner semptomlar ve inkontinansın yaşam kalitesine etkisi (Yüksek Lisans Tezi). İstanbul, İstanbul Üniversitesi, 2016.

40. Özerdoğan N. Eskişehir, Bilecik, Afyon, Kütahya illerinde 20 yaş ve üstü kadınlarda inkontinansın prevalansı, risk faktörleri yaşam kalitesine etkisi (Doktora Tezi). İstanbul, İstanbul Üniversitesi, 2003. 
41. Dinç A. Üriner inkontinans şikayeti olan gebelerde gebelik ve postpartum dönemde uygulanan pelvik taban kas egzersizlerinin bu şikayetin giderilmesindeki etkinliği (Doktora Tezi). İstanbul, İstanbul Üniversitesi, 2004.

42. Aslan E. Huzurevinde yaşayan Üriner şikayetleri olan kadınlarda mesane eğitimi ve kegel egzersizlerinin etkinliği (Doktora Tezi). İstanbul, Marmara Üniversitesi, 2005.

43. Sarı D. Pelvik taban kas egzersizlerinin üriner inkontinans ve yaşam kalitesine etkisi (Doktora Tezi). İzmir, Ege Üniversitesi, 2007.

44. Kocaöz S. Gebelik döneminde stres üriner inkontinansı (SÜi) önlemeye yönelik uygulanan pelvik taban kas egzersizlerinin doğum sonrası etkinliğinin incelenmesi (Doktora Tezi). Anakara, Hacettepe Üniversitesi, 2007.

45. Uyar Hazar H. Ürinerinkontinansı olan romatoidartritli kadınlarda eğitimin etkinliğinin incelenmesi (Doktora Tezi). İzmir, Ege Üniversitesi, 2008.

46. Zengin N. İdrar kaçıran kadınlarda hemşirelik eğitimi ve davranışsal tedavinin konfor, pelvik taban kas egzersizi uygulaması öz-etkililik algısı ve yaşam kalitesine etkisi (Doktora Tezi). İstanbul, Marmara Üniversitesi, 2008.

47. Topuz Ş. Üriner inkontinansta uygulanan kegel egzersizlerinin kadın cinsel doyumu üzerine etkisi (Doktora Tezi). Kayseri, Erciyes Üniversitesi, 2016.
48. Bilgiç Çelik D. Üriner inkontinans ve/veya pelvik organ prolapsus cerrahisi uygulanan kadınlarda yaşam kalitesi ve cinsel işlevin değerlendirilmesi (Doktora Tezi). İstanbul, İstanbul Üniversitesi, 2012.

49. Terzoni S, Montanari E, Mora C, Destrebecq A. Urinary incontinence in adults: nurses' beliefs, education and role in continence promotion. A narrative review. Arch Ital Urol Androl 2011;83: 213-6.

50. Kelleher C, Radley SC. Quality of Life and Urinary Incontinence. In: Cardoza L, Staskin D (eds). Textbook of Female Urology and Urogynecology. 2nd edition. London: Informa Healthcare; 2001;64-5.

51. Aslan G, Koseoglu H, Sadik O, Gimen S, Cihan A, Esen A. Sexual function in women with urinary incontinence. Int J ImpotRes 2005;17:248-51. [CrossRef]

52. Giuseppe PG, Pace G, Vicentini C. Sexual function in women with urinary incontinence treated by pelvic floor transvaginal electrical stimulation. J Sex Med 2007;4:702-7. [CrossRef]

53. Başgöl Ş. Cinsel fonksiyon bozukluğu olan kadınlarda interaktif biofeedback tedavisinin cinsel fonksiyon ve yaşam kalitesi üzerine etkisi (Yüksek Lisans Tezi). İstanbul, İstanbul Üniversitesi, 2013.

54. Dumoulin C, Hay-Smith J. Pelvic floor muscle training versus no treatment, or inactive control treatments, for urinary incontinence in women. Cochrane Database Syst Rev 2010;20:CD005654. [CrossRef] 